\title{
Gniazdo słowotwórcze wyrazów motywowanych nazwą własną Coдoм w dyskursie radykalnego ruchu prawosławnego we współczesnej Rosji
}

\author{
The word-formation nest of words motivated by a proper \\ noun Содом in a discourse of the radical Orthodox Church \\ movement in modern Russia
}

\begin{abstract}
One of the important issues discussed in discourse texts of the radical Orthodox Church movement in Russia is the area of man's sexual life, including the issue of homosexuality. In the studied texts, resources of nominations referring to sexual orientation and homosexual people are relatively small. The group of lexemes referring to homosexuality, mainly male, most numerously represented in the studied material and most diversified grammatically is the word-formation nest of words motivated by the proper noun Sodom (Содом). The elements of the word-formation nest with the stem содом- are usually used in the text because, due to their significantly axiological character, they make unnecessary the use of other strongly axiological units belonging already to lower stylistic registers. It is also not surprising that in the conservative and Orthodox Church circles the units of biblical origin prevail, and the richness of their forms definitely confirms their current importance in the studied discourse.
\end{abstract}

Keywords: Sodom, conservative, Orthodox Church, discourse in Russia, homosexuality

Piotr Zemszał, Uniwersytet Mikołaja Kopernika w Toruniu, Toruń - Polska, howie@umk.pl, ORCID ID: https://orcid.org/0000-0002-0822-8937

Radykalny ruch prawosławny w ostatnich latach przybrał na sile na fali poszukiwania nowej ideologii jednoczącej rosyjskie społeczeństwo i konsolidującej państwo, która potocznie określana bywa jako духовныле скрепьл. Lektura licznych materiałów zamieszczonych na jednym z popularniejszych portali publikujących i agregujących treści pojawiające się w innych źródłach związanych z tym środowiskiem pozwala na wskazanie podstawowych założeń ideologicznych spajających je. Portal, o którym mowa, nazywa się Москва - Третий Рим (https://3rm. info/) i jest źródłem materiału będącego podstawą niniejszego opracowania. Jak wynika z informacji na stronie, portal został założony w 2009 roku. Oficjalna 
nazwa źródła brzmi: Православный информационно-аналитический портал (ПИАП) ,,Москва - Третий Рим”, przy czym na samej stronie nie mamy szansy poznać żadnych szczegółów na temat administratorów tego zasobu. Sam portal, według statystyki podawanej przez stronę liveinternet.ru, przeglądany był w październiku, listopadzie i grudniu 2018 roku średnio przez 56808 osób miesięcznie (Liveinternet.ru, źródło elektroniczne), maksymalna liczba odwiedzających w ciągu jednego dnia wyniosła nieco ponad 120 tys. Jeśli dodać do tego liczbę czytelników cytowanych przezeń źródeł (np. „Русь-Фронт” - 41698 odwiedzających, dane rankingu Rambler/top 100, źródło elektroniczne), to uzyskamy liczbę może nie oszałamiającą, ale znaczącą. Poszczególne materiały czasopisma przeglądane są od kilku do kilkudziesięciu tysięcy razy. Rekordowy tekst САТАНИНСКИЙ ПРОЕКТ „ВLUE ВЕАM”. Построение ияарства антихриста ${ }^{1}$ opublikowany 26 lipca 2018 roku w ciągu niespełna półrocza (do 30 grudnia) zanotował 732237 odsłon. Kwerenda objęła 787 tekstów publikowanych na portalu w latach 2016-2018. Podczas gromadzenia materiału pomijałem teksty nieistotne z punktu widzenia światopoglądowego (np. poświęcone sposobom przeprowadzenia miodobrania czy suszenia grzybów, ziół itp.) oraz poświęcone wierze ${ }^{2}$ sensu stricto (np. opracowania hagiograficzne i teksty modlitw publikowane $\mathrm{w}$ dniach poświęconych określonym świętym). Wśród wielu tematów podejmowanych na łamach portalu (np. kwestia ekumenizmu, wojna na Ukrainie, relacje Rosji z Zachodem, krytyka kultury masowej itd.) dość istotne miejsce zajmują kwestie związane z seksualnością człowieka, a zwłaszcza ze zjawiskiem zdecydowanie źle waloryzowanej homoseksualności.

Celem niniejszego artykułu jest, po uprzednim zebraniu dostępnych informacji natury leksykograficznej, przybliżenie ogólnej pragmatyki jednostek leksykalnych motywowanych nazwą własną Содом dominującej w warstwie nominacyjnej tych spośród badanych tekstów, które dotyczą wymienionego zagadnienia. Postaram się zatem na podstawie odnotowanych przypadków przybliżyć potencjał pragmatyczny analizowanych jednostek ze szczególnym uwzględnieniem pewnych ograniczeń, które na swoje wypowiedzenia zdają się nakładać sami autorzy (np. unikanie wulgaryzacji języka) oraz tła historyczno-kulturowego, jakie stanowi konserwatywna doktryna prawosławna.

Trudno jednoznacznie stwierdzić, czy badany dyskurs jest homofobiczny. Gregory M. Herek zauważa, że aktywiści chrześcijańscy podkreślający, że termin homofobia nie znajduje zastosowania w opisie ich postawy, mogą mieć do pewnego stopnia rację, ponieważ ich motywacją nie jest strach, a przekonania religijne

\footnotetext{
${ }^{1}$ Zapis zgodny z oryginałem.

2 Wierze, a nie religii, sprawy religijne bowiem, jak np. kwestia ekumenizmu, bywają w badanych materiałach ściśle splecione z kwestiami społeczno-politycznymi.
} 
(Herek 13). Omawiane pojęcie wydaje się zresztą mało przydatne w rozważaniach naukowych, ponieważ nie osiągnięto jego jednoznacznej definicji, a ponadto został on silnie zideologizowany. Niemniej jednak wyraźnym rysem badanego dyskursu, bez względu na motywacje, do których oceny nie czuję się kompetentny, jest stygmatyzacja osób o orientacji homoseksualnej i homoseksualizmu jako takiego. Ta „linia wrogości” jest bardzo wyraźna. Jak twierdzi Aleksiej Zygmont, „sodomici” stanowią obok „sekciarzy” kategorię najczęściej atakowaną przez osoby wierzące w Rosji, przy czym jest to kategoria osób poddawana najdalej idącej dehumanizacji (Zygmont 136-137). Osoby niewpisujące się w tradycyjny model seksualności są zaś coraz częstszym obiektem fizycznej agresji, przy czym aż w 77\% dotyczy to homoseksualnych mężczyzn (Laboratoriâ issledovanij seksual'nosti, źródło elektroniczne).

W badanych tekstach funkcjonuje dość niewielki zasób nominacji odnoszących się do orientacji seksualnej i osób homoseksualnych. Nie znajdziemy tu licznych określeń charakterystycznych dla agresywnego, wulgarnego dyskursu homofobicznego, których pozwolę sobie nie wymieniać. Rzadkość tego typu użyć wynika najprawdopodobniej z postulowanego i swoiście pojmowanego puryzmu językowego propagowanego na łamach badanego portalu. Ten puryzm językowy wydaje się jednak postawą dość powierzchowną, by nie rzec - faryzejską. W oznaczeniach zdjęć ilustrujących materiał pod tytułem ОБНОВЛЕНО. ПРОДОЛЖЕНИЕ... КАК МЫ ПЕДЕРАСТОВ ГОНЯЛИ. Изп ервыху $\mathbf{c m}$. $(\text { ВИДЕО, ФОТО })^{3}$, które, najprawdopodobniej w wyniku błędu technicznego, są widoczne dla czytelnika, podobnie jak w komentarzu redakcyjnym do materiału (tekst spoza chronologicznego zakresu kwerendy) znajdujemy jednostkę пидор zapisaną łacinką: pidory. W ten sposób podpisano 5 z 6 zdjęć (Moskva - Tretij Rim, źródło elektroniczne). Jednak wewnątrzportalowa wyszukiwarka na zapytanie пидор wskazuje zaledwie 5 wyników, podczas gdy zapytanie гомосексуалист daje ich 50 (jest to górna granica ustawień samej wyszukiwarki, wyników tych jest zapewne więcej, 50 wyników dają również zapytania церковь і Москва, stan z 4 stycznia 2019 roku).

Najliczniej reprezentowaną w badanym materiale i najróżnorodniejszą pod względem gramatycznym grupę leksemów odnoszących się do homoseksualności, również głównie wśród mężczyzn, stanowi gniazdo słowotwórcze wyrazów motywowanych nazwą własną Содом (łącznie 296 wystąpień). Należą do niej następujące jednostki: (C)содом (19 wystąpień), (Е)евросодом (9 razy), содомит (68 wystąpień, w liczbie pojedynczej zaledwie 18), содомитка (1 wystąpienie w liczbie mnogiej, patrz wyżej), содомлянин (11 wystąpień, wszystkie w liczbie mnogiej), содомия (pojawia się 27 razy), содомизм (3 razy), содомитство

\footnotetext{
3 Zapis zgodny z oryginałem.
} 
(4 razy), содомский (45 razy), содомитский (6 razy), содомски (1 raz), осодомиться (1 raz), содомизация (1 raz).

Sodoma (Содом) to opisane w Biblii (Rdz 19) miasto, które wraz z Gomorą zostało ukarane „deszczem siarki i ognia od Pana” (Rdz 19, 24) za rozpustę. Opowieść o zniszczeniu Sodomy jest jednym z nieodłącznych elementów tradycji judeochrześcijańskiej, a sama nazwa stała się symbolem niemoralnego, z punktu widzenia doktryny, postępowania w sferze seksualnej. Pytanie, które należy zadać, brzmi: w jakim stopniu charakter przewin, będących przyczyną ukarania w tej opowieści Sodomy, można wiązać z homoseksualnością, a co za tym idzie, jakie jest miejsce pojęcia homoseksualności w strukturze semantycznej derywatów nazwy Sodoma (Содом). Co ciekawe, w definicjach apelatywizowanej ${ }^{4}$ formy содом ten element nie występuje (Dal' 266; Fasmer 706; Kuznecov 1229; Ožegov 607; Bogatova 92; Sorokoletov 211-213; Švedova 913). W słowniku Aleksandra Czudinowa z 1894 roku definicja w haśle Содомъ ogranicza się jedynie do objaśnienia geograficzno-historyczno-biblijnego: „Древній городъ у Мертваго моря, жители котораго предавались разврату, за что и былъ истребленъ небеснымъ огнемъ, вмъсть съ Гоморрою; отсюда вообще городъ съ испорченными нравами" (Čudinov 607-608). W słowniku tym dopiero jednostki derywowane od nazwy własnej Содом (a nie od apelatywizowanej formy содом) we wzajemnym powiązaniu wykazują bezpośrednią obecność semantycznej sfery seksualności człowieka:

Содомитъ (по им. города Содома). Человђкъ, предающійся содомскому грђху;

Содомскій грьхъ (оть имени города Содома, въ которомъ употреблялся).

Противоестественное удовлетвореніе полового побужденія - мужеложство (Čudinov 607).

Dość szeroko do sfery seksualności człowieka, w tym do homoseksualności, odwołują się definicje zawarte w historycznym słowniku obejmującym okres XIXVII wieku (tom 26):

СОДОМЛЯНИНЪ, м. Порочный человек, особенно приверженный мужеложеству - от названия г. Содом в Ханаане;

СОДОМСКИ (-СКЫ), нареч. 1. Подобно жителям Содома, погрязшим в грехах [...] 2. Противоестественно (о половом сношении между мужчинами, а также per anum) - по

${ }^{4}$ Warto przytoczyć w tym miejscu najkrótszą choćby definicję apelatywizacji: „Apelatywizacja to proces przechodzenia nazwy własnej w rzeczownik pospolity, czyli przechodzenia nomen proprium w nomen appellativum" (Długosz-Kurczabowa 5). Nieco bardziej wyrafinowane podejście do tej kwestii prezentuje, powołując się na innych autorów, Mariusz Rutkowski, który podkreśla, że apelatywizacja nie jest prostym „przejściem”, ale w jej wyniku pojawia się nowa jednostka leksykalna, która wchodzi z onimem w relację homonimii (Rutkowski 28). 
имени г. Содом в Ханаане, жители которого предавались этому пороку (ср. Быт. XIX, 5) (Bogatova 92);

СОДОМСТВО, $c$. «Содомский» грех, противоестественные половые отношения per anum (Bogatova 93).

W większości z dziewięciu zbadanych pod tym kątem słowników w ogóle nie ma jakichkolwiek elementów tego gniazda słowotwórczego, których definiensy bezpośrednio nawiązywałyby do sfery seksualnej ${ }^{5}$. Co prawda przy definicjach leksemu Содом przytaczana jest biblijna etymologia, ale sfera seksu jest w niej obecna jedynie pośrednio, np.:

Безнравственность, распущенность, разврат, парящие где-л. $\diamond$ Содом и Гоморра. Полный беспорядок, хаос, беззаконие. • От названия древних палестинских городов Содома и Гоморры, которые, по библейскому рассказу, были уничтожены землетрясением и огненным дождем за ужасающее беззаконие ${ }^{6}$ их жителей (Kuznecov 1229)

СОДОМ, -а, м. (разг.). Беспорядок, шум, суматоха. Подняли целый с. Содом и Гоморра (книжн.) - полный беспорядок, хаос [от названии городов, по библейской легенде, разрушенных стихией за грехи жителей] (Ožegov 607)

СОДО’М, -а, $\boldsymbol{M}$. (разг.). Беспорядок, шум, суматоха. Поднять $c$. Содом и Гоморра (книжн.) - полный беспорядок, хаос [от названий городов, по библейскому сказанию, разрушенных и испепелённых Богом за распутство их жителей], прил. содомский, -ая, -ое. Содомский грех (книжн.) - оргия, сопровождаемая противоестественными ${ }^{7}$ половыми отношениями [podkreślenie moje - P.Z.]. От назв. Города Sodoma в Древней Палестине (Švedova 913).

Najszerzej, i chyba wyjątkowo, omawiane gniazdo słowotwórcze reprezentowane jest w elektronicznym słowniku Uszakowa (Ušakov). Definiowane są tu jednostki:

${ }^{5}$ W słowniku Dala są to leksemy derywowane od zapelatywizowanego już rzeczownika содом: „Содо́мить шумъть, кричать, гамить, орать толпою, горланить, браниться, ругаться; поднятьш умъ, брань, ссору. Сльшшь, въ кабакљ содомятъ какъ! -ся, влд. шумъть, кричать, браниться, ругаться. Содо́мная, содо́мливая сходка, бестолковая и шумная, крикливая. Содомко говорить, влгд. громко, шумно, крикливо. Содо́мщикъ, содомщцца сварливый орала, затейщикъ ссоръ” (Dal' 266); słownik Fasmera: „содомить «шуметь, кричать»” (Fasmer 706).

${ }^{6}$ Tutaj semantyka seksualna w ogóle nie występuje.

7 Znowu, podobnie jak w słowniku XI-XVII wieku (Bogatova 93), pojawia się określenie противоестественный, które, o ile zakładać, że zadaniem definicji słownikowej nie jest wartościowanie, nie powinno się w niej pojawić. Wydaje się to błędem tym bardziej, że semantyka tego przymiotnika jest w znacznej mierze nieokreślona i może on być w kolokacji противоестественнье половые отношения interpretowany bardzo rozmaicie. 
содом - 1. Крайний беспорядок, сильный шум, суматоха (разг. шутл.). 2. Шумная, буйная толпа (устар.). Шутов и дур содом. И. Дмитриев. а Содом и Гоморра (ритор.) - 1) то же, что содом, но в более сильной степени; 2) разврат, развратнаяж изнь. (По имени древних городов южной Палестины - Содома и Гоморры, к-рые, по библейской легенде, были разрушены огненным дождем и землетрясением за грехи жителей.);

содомизм - (книжн., мед.). Склонность к содомии;

содомит - (мед.). Человек, подверженный содомии, склонный к содомии (см. содомия в 1 знач.);

содомитка - (мед.). Женск. к содомит;

содомить - (простореч. шутл.). Устраивать содом (см. содом в 1 знач.), шуметь, ругаться, браниться;

содомия - (книжн.). 1. Скотоложество. 2. Педерастия, мужеложество (устар.). (По имени города Содома, см. содом.)

содомский - (книжн. устар.). Греховный, развратный, преступный. Содомский грех (церк., книжн. устар.) *_* то же, что содомия (Ušakov).

W badanym materiale daje się zauważyć odwrotna tendencja niż zaobserwowana w większości słowników. Nie ma w nim bowiem jakichkolwiek użyć leksemów tej grupy, które nie odnosiłyby się do sfery seksualności człowieka, głównie do praktyk homoseksualnych, np.:

(1) Когда-то казалось невозможным даже упоминать вслух об извращениях, названных медициной „педерастия”, а Библией - „содомия” ... [1]

(2) Недаром же главный содомит Украины, глава „гей-форума” Святослав Шеремет заявляет, что „вся оппозиция к нам церковная, или околоцерковная" [2].

(3) Сам факт того, что во главе Св. Престола стоит содомит, породила у части гомосексуалистов желание не только стать священниками, но и сформировать свой собственный религиозный орден [3].

Zgodnie z tym co twierdził Derrick S. Bailey (cyt. za Sozaev 59), utożsamienie pojęcia sodomii z praktykami homoseksualnymi bynajmniej nie wynika w oczywisty sposób z interpretacji biblijnej historii Sodomy. W tradycji rabinicznej „grzech Sodomy” był interpretowany jako brak gościnności, a skojarzenie tego pojęcia z homoseksualnością pojawia się dopiero w Kodeksie Justyniana ${ }^{8}$ (pierwsza połowa VI wieku). To dość późne powiązanie biblijnej historii unicestwionego za swoje grzechy miasta $\mathrm{z}$ homoseksualnością jest wyrazem zaostrzenia oceny samego zjawiska. Skoro bowiem grzech Sodomy wymagał bezpośredniej i bezwzględnej reakcji Boga, był to grzech najcięższy z możliwych9. W tym

${ }^{8}$ Corpus iuris civilis, novella 141.

9 Jak twierdzi James Allan Evans, to zaostrzenie podejścia do homoseksualizmu (właściwie stanowcze potwierdzenie wprowadzonej przez Kodeks Teodozjusza kary śmierci poprzez ścięcie) było sprowokowane serią trzęsień ziemi (jedno z nich doprowadziło do pęknięcia kopuły w kościele Hagia Sophia) i epidemiami dżumy w 542 i 558 roku (Evans 75). 
powiązaniu tkwi również źródło skrajnie negatywnego nacechowania całego gniazda słowotwórczego ${ }^{10} \mathrm{w}$ badanym dyskursie.

Jednostki należące do gniazda słowotwórczego fundowanego na rdzeniu coдом- często $\mathrm{w}$ badanym materiale występują w podobnych kontekstach jak leksemy z rdzeniem гомосексуал-, które bywają traktowane jako neutralne. Są one jednak, przez swoje odwołanie do historii Sodomy, zdecydowanie mocniej nacechowane. W dyskursie kierowanym do osób znających biblijny kontekst stanowią nie tyle nawet sygnał negatywnej oceny, ile swoiste wezwanie do zajęcia aktywnego stanowiska. Skoro bowiem Bóg zareagował, niszcząc Sodomę, to znaczy, że jej mieszkańcy na to zasługiwali, a zatem i współcześni „sodomici” winni być zneutralizowani, o ile nie w ogóle zniszczeni. W jednym z badanych tekstów znajdujemy wiele historycznych przykładów pozytywnie waloryzowanej przez autora badanej wypowiedzi walki z homoseksualnością, przy czym niekoniecznie odnoszących się do tradycji chrześcijańskiej, np.:

(4) И в исторические времена за содомские грехи и разврат целые города истреблялись с лица земли. Tак, в XIV в. обратились к Тамерлану за помощью женщины Багдада и Дамаска. Они жаловались на своих мужей, которые погрязли в мужеложстве. „Железный хромец” немедленно произвёл расследование, на котором развратники признались в скотских грехах. Тогда Тимур дал приказ своим военачальникам: „Пусть каждый из воинов моей 700-тысячной армии в течение двух дней принесёт отрубленную голову мужеложника. Если какой воин пожалеет злодея, пусть сам останется без головы”. И выложили семь пирамид из голов, по сто тысяч в каждой - в назидание потомкам [4].

Tekst kończy się wezwaniem:

(5) Сегодня, как никогда, за наших детей нужно бороться не на жизнь, а на смерть [4].

$\mathrm{W}$ parze z takim postrzeganiem kwestii homoseksualności, którego wyrazem jest częste (najczęstsze w badanych tekstach) posługiwanie się elementami omawianego gniazda słowotwórczego, pojawiają się liczne cechy przypisywane „sodomitom”, charakteryzujące ich jako środowisko obce, ekspansywne, a nawet agresywne. Zdecydowana większość odnotowanych użyć pojawia się w kontekstach dotyczących Zachodu, np.:

${ }^{10} \mathrm{O}$ jego potencjale pisze Nadieżda Orłowa: „Прецедентная ситуация «Гибель Содома [и Гоморры]»- одна из самых значимых и трагических в Библейском тексте - и одна из наиболее освоенных русской и европейской литературой и культурой. Эта освоенность проявляется в первую очередь в том, что сигналом данной прецедентной ситуации (ПС) в различных дискурсах служит концепт 'содом', обладающий огромными когнитивными потенциями [...]" (Orlova 47). 
(6) Сегодня содомитство стало образом жизни большей части Америки [33];

(7) В США, Англии, Германии и других западных странах содомитство не только легализовано, но и имеет льготы [4];

(8) И если Европа так привержена содомской мерзости, тогда скатертью им дорога в ад [5].

Skojarzenie homoseksualności, czyli, trzymając się terminologii motywowanej biblijnie, sodomii ze światem Zachodu, który wobec tego skojarzenia nie może być waloryzowany pozytywnie, skutkuje pojawieniem się złożenia Eвpoсодом ${ }^{11}$, funkcjonującego jako hasło wywoławcze (podkreślane często poprzez zastosowanie czcionki wersalikowej) w narracjach dotyczących liberalizmu obyczajowego w Europie. Na przykład:

(9) Достоевский против евросодома. Сегодня актуально, как никогда! [6];

(10) Евросодом. За отказ от секспросвета - тюрьма! [7];

(11) Обозревший Евросодом... Еврокомиссия обвинила патриарха Илию II в нетолерантности [8];

(12) Адский Евросодом... Для тех, кто хочет в Европу. Детские площадки в педофильском стиле [9].

W funkcji swoistego hasła dla określonego zakresu tematycznego funkcjonuje też formuła планета Содом, nр.:

(13) Планета Содом... Пропаганда извращений для детей: Дисней снимает первый фильм о педерасте [10];

(14) Планета Содом... „Гомосексуализм” стал предметом в школах США [11];

(15) Планета Содом... Технология продвижения извращений в России [12];

(16) Планета Содом... Содомиты готовят массированное нападение на Россию [13].

Trzykrotnie w badanym materiale pojawia się parafraza nazwy Stanów Zjednoczonych odwołująca się do rzekomego zdominowania tego obszaru przez wpływy środowisk homoseksualnych:

(17) Содомские Штаты Америки... В Нью-Йорке в свидетельствах о рождении появилась гендерно-нейтральная категория „Х” [14];

(18) США - Содомские Штаты Америки... Сенат штата Иллинойс проголосовал за преподавание истории ЛГБТ в школе [15];

${ }^{11}$ Por. „Не могу отделаться от ощущения, что это сказано о нынешней содомитской Европе. Разве европарламент, еврокомиссии и прочие демонские их сборища не являются современными содомлянами, проводниками греха и противоестественых извращений?” [17]. 
(19) Содомские Штаты Америки - США... Калифорния вводит запрет на ,попытки лечения” содомии [16].

Wszystkie wymienione formuły służą uwypukleniu podziału na opanowany przez homoseksualistów obszar Zachodu i z trudem broniącą się przed tym wpływem Rosję:

(20) Зри в корень... Содом в предвкушении победы над Россией [18];

(21) Тезис о собственной исключительности и предпочтительности модели поведения и образа жизни стал знаменем гомосексуалистов, и никакие флаги мира их более не устраивают - содом рвётся в решающий бой. И главная цель здесь - Россия, ведь узаконивание в ней содомии автоматически обрушит весь остальной христианский мир [18];

(22) Мировой содом пошёл в открытый бой с традиционным обществом в 70-х годах прошлого века [19].

Rosja jest tu przedstawiana jako ostatni bastion broniący cywilizacji chrześcijańskiej przed agresją wojującego homoseksualizmu, który opanował już cały świat [всемирный (глобальныий) содом], przy czym to opanowanie dokonuje się w pewnej zorganizowanej formie poprzez tworzenie lub podporządkowanie sobie struktur władzy (содомократия), пр.:

(23) На пути мировой содомократии стоит Россия [1];

(24) Только после полного извращения христианского вероучения [...] может восторжествовать всемирный Содом [2].

Wiąże się to z kategorią rzekomej ekspansywności środowisk LGBT, której bezpośrednimi wykładnikami są takie leksemy, jak należące do metaforyki militarnej rzeczowniki наступление і нападение, czasownik нападать:

(25) Началом наступления мирового содома на Россию следует считать 8 марта 2017 г. [18];

(26) Впрочем, на этом наступление боевых содомитов на Россию пока захлебнулось [13];

(27) Содомиты готовят массированное нападение на Россию [13];

(28) Теперь содомиты, похоже, решили нападать на всех подряд [13].

Co istotne, ,Sodoma” prezentowana jest jako zorganizowana siła, która w globalnej skali bierze górę, a to potęguje wrażenie oblężonej twierdzy. W badanych tekstach pojawiają się takie związki wyrazowe, jak всепобеждаюший содом, всепобеждающее шествие содомократии, победное иествие oraz metaforyczne formuły fundowane na czasownikach захлеснуть і накрыль о ogólnym znaczeniu 'zdominować', np.:

(29) Это - историческое событие, [...] создающее новую реальность „всепобеждающего содома” [20];

(30) И, выходит, теперь только они [верующие] мешают всепобеждающему шествию содомократии в мире [1]; 
(31) Содомия захлестнула восходящую звезду бесовской эстрады [21];

(32) С подачи королевского дома Англии мир накрывает содомская революция [20];

(33) Гендерные технологии начали победное шествие по России. Извращенцы ликуют вместе со всемирным Содомом [22].

Obok „frontalnego ataku” homoseksualny „wróg” działa również w sposób bardziej ukryty, podstępny, mniej jawny (вползать куда-л., проталкивать, проникновение, пропихнуть), $\mathrm{np}$.:

(34) Содомитска мерзость вползает в Церковь... [23];

(35) В особенности же пугает проникновение в церковную ограду страшнейшего содомского греха - гомосексуализма [24];

(36) Либеральная тусовка проталкивает Содом и Гоморру в Православную Церковь [25];

(37) $[. .$.$] мощное „гей-лобби” в органах власти РФ [...] держит патри-$ отов в напряжении, то и дело норовя пропихнуть очередную инициативу от глобального Содома [13].

$\mathrm{Z}$ badanych tekstów wynika pewna interesująca prawidłowość - frontalne formy ,ataku” wymierzone są bowiem w Rosję (prezentowaną w badanym dyskursie jako jedyną prawdziwie chrześcijańską cywilizację) jako całość, natomiast celem ofensywy „ukrytej” we wszystkich odnotowanych przypadkach jest Cerkiew bądź środowisko określone w ostatnim przykładzie jako nampuombl. Taki podział sprzyja wytworzeniu wrażenia, że oto mamy do czynienia z dwiema liniami „obrony”, z czymś, co odpowiadałoby fortyfikacyjnej konstrukcji dolnej i górnej twierdzy, gdzie pierwszą linią obrony jest Rosja (dolna twierdza), a drugą (górną twierdzą, cytadelą) - Cerkiew i środowiska „patriotyczne”. Druga linia obrony jest przy tym mocniejsza, jej obsada jest na frontalny atak odporna i należy wobec niej działać za pomocą podstępu i fortelu.

Ekspansywny charakter środowisk LGBT podkreślany jest w badanych tekstach również poprzez odwołanie się do metafory choroby i zakażenia/zarażenia oraz czasowników i ich derywatów oznaczających działanie w kierunku rozprzestrzenienia czegoś z pozycji siły (насаждать, навязывать) nр.:

(38) $[. .$.$] они восхищаются „талантами” тех, кто заражает мир содом-$ ской гнилью... Эти матери - более, чем убийцы... [26];

(39) Эта педерасня заражает наших детей всеми смертными страстями и грехами, губящими души [27];

(40) Парады содомитов, так называемые „парады гордости” - это один из инструментов мощного механизма социального заражения... [19];

(41) Цель Запада - принудить малороссов и проживающих в Черногории и Македонии сербов к отказу от своего прошлого, отказу от 
своей национальной идентичности, навязать им содомские „ценности”, перековать их в покорных рабов и слуг нового мирового порядка [28];

(42) Чего только стоит его роль в „Интернах”, где насаждается блуд, содомия, лживость, пьянство, прочие грехи и страсти [29];

(43) Беда наша в том, что мы, возмущаясь открытым насаждением содомского греха, терпимо относимся и даже порой оправдываем его „умеренные” проявления [6].

W analizowanych przykładach znalazły się również dwa leksemy odnoszące się do efektu tych ekspansywnych działań - содомизаиия і осодомиться:

(44) Бенедикт немного уперся против содомизации - разрушения основ христианской этики [30];

(45) Затем осодомилось вероучение множества протестантских сект [2].

O ile negatywne nacechowanie elementów gniazda słowotwórczego rdzenia гомосексуал- należało wykazać m.in. poprzez przywołanie ilustracji, w których występowały one na równorzędnych zasadach z innymi ujemnie wartościującymi jednostkami, o tyle w przypadku derywatów nazwy własnej Содом nie wydaje się to konieczne. Jednak przyjrzenie się tego typu kontekstom ujawnia pewną istotną różnicę. W przypadku rdzenia гомосексуал- w badanych materiałach współwystępowały reprezentacje pojęć z zakresu zjawisk społecznych czy indywidualnego behawioru człowieka (np. педофилия, алкоголики, наркоманы, разврат, терроризм, избиение беременных женщин). W kontekstach zawierających jednostki derywowane od nazwy własnej Содом pojawiają się leksemy należące do innego pola semantycznego związanego już ze sferą sakralną. Jednostki te, poczynając od formuły содомский грех, przenoszą dyskurs z obszaru „codzienności” do obszaru metafizycznego starcia dobra ze złem, np.:

(46) Парады содомитов, по словам очевидцев, - это настоящее сатанинское сборище [4];

(47) Содомия захлестнула восходящую звезду бесовской эстрады [21];

(48) И если Европа так привержена содомской мерзости, тогда скатертью им дорога в ад [5];

(49) Но лучше умереть в бою, чем быть в жидоантихристовом, сатанинском, содомском, «новом міровом порядке»! [31];

(50) Антихристов концлагерь уже являет себя в Евросодоме... [32];

(51) Адский Евросодом... Для тех, кто хочет в Европу. Детские площадки в педофильском стиле [9];

(52) А „благославлял” все это содомско-сатанинское сборище... католический священник [33];

(53) Но мы же знаем, что все эти взаимные выпады с истериками феминисток и мужского движения, это вовсе не забавная игра и троллинг 
с запасом попкорна, а работа диавола по насаждению ненависти и содомии среди мужчин и женщин [34];

(54) Евросодом... Глубины Сатанинские. В Европе оправдывают педофилию [35].

Genetyczna więź ze sferą sakralną aktualizuje się w badanych tekstach niemal automatycznie, co skutkuje wyraźnie mocniejszym nacechowaniem derywatów nazwy własnej Содом w porównaniu do elementów gniazda słowotwórczego rdzenia гомосексуал-. Zdecydowanie mocniej wybrzmiewają również leksemy wchodzące w związki wyrazowe z tymi derywatami: содомская гниль, содомитская мерзость, вонючий содомит, содомская зараза, содомская скверна, сборище содомитов, сатанинская содомия.

Wśród nominacji dotyczących osób homoseksualnych na pierwszy plan pod względem liczby odnotowanych użyć wysuwa się jednostka содомит. Podobnie, jak w przypadku nominacji гомосексуалист, również w liczbie mnogiej dotyczy ona zwykle mężczyzn (Kon 10). Z jednej strony waloryzacja, którą ze sobą niesie, motywowana jest biblijną opowieścią o tych, których należało zniszczyć, a więc jest jednoznacznie negatywna, ale z drugiej strony - nie jest to leksem w jakimkolwiek stopniu wulgarny, co ma duże znaczenie dla dyskursu, w którym wciąż podkreśla się, że wulgaryzacja języka jest złem. Swoją drogą, najbardziej nawet wulgarne określenia osób homoseksualnych pod względem aksjologicznym pozostają daleko w tyle za omawianą nominacją, jednoznacznie sytuującą denotat w kręgu metafizycznego zła. Omawiana jednostka pozwala więc nadawcom realizować szeroki zakres funkcji pragmatycznych (wyrażenie pogardy, potępienie, ośmieszenie, dyskredytacja itd.) przy jednoczesnym uniknięciu wulgaryzacji komunikatu.

Najczęściej występującym elementem omawianego gniazda słowotwórczego jest również nominacja содомит, której łańcuch słowotwórczy wygląda następująco: Содом - содомия - содомит. Jest to synonim nominacji гомосексуалист. W badanych tekstach pojawia się jednak również nominacja содомлянин, której łańcuch słowotwórczy jest krótszy: Содом - содомлянин. Zgodnie z budową (sufiksy -ян, -ин) ogólna semantyka tego typu nominacji daje się sprowadzić do znaczenia 'mieszkaniec danego obszaru', np. киевлянин, северянин. Tak też pierwotnie było w przypadku rzeczownika содомлянин, oznaczającego mieszkańca Sodomy:

(55) Еще не легли они спать, как городские жители, содомляне, от молодого до старого, весь народ со всех концов города, окружили дом [Книга Бытие 19: 4].

To znaczenie jest $\mathrm{w}$ badanych tekstach jak najbardziej aktualne w narracjach odwołujących się do biblijnej historii Sodomy, np.:

(56) Так что же мы, русские люди, не смотрим вглубь истории, чтобы набраться мудрости и не унаследовать участи ниневитян или содомлян? [36]. 
Jednak w badanym materiale daje się zaobserwować również interesujące przesunięcia znaczenia rzeczownika содомлянин w kierunku nominacji содомuт. Występują one w identycznych kontekstach, np.:

(57) Поэтому парады содомитов, [...] с мистической стороны можно рассматривать, как ритуальное осквернение улиц и городов [37];

(58) Он должен противостоять массовому развращению людей, в том числе парадам содомлян... [37].

W związku z tym, że użyć nominacji содомлянин nie odnotowano zbyt wiele (11 takich przypadków) i większość z nich (7 przypadków) odnosi się do mieszkańców Sodomy, należałoby uznać, że jest to jedynie przypadkowa zbieżność. Kryje ona w sobie jednak pewien istotny potencjał retoryczny. Chodzi tu o powiązanie semantyki przestrzennej obecnej w nazwach mieszkańców określonego terytorium z negatywną waloryzacją charakterystyczną dla nominacji codoмит. Byłoby to idealne przedłużenie koncepcji Евросодома (планета Содом, Содомские Штаты Америки), wiążącej określony model swobody seksualnej (содомский грех) z kulturą Zachodu. Tę tezę może potwierdzać dystrybucja przymiotników содомитский і содомский, derywowanych odpowiednio: Содом содомский (tj. odnoszący się do miasta Sodoma), Содом - содомия - содомит - содомитский (tj. homoseksualny). Podobna relacja między przymiotnikami będzie potwierdzeniem zaobserwowanej tendencji.

(59) Содомитские организации в разных странах мира издают свои газеты... [4];

(60) Становятся модными содомитские свадьбы [4];

(61) Первая страна, которая признала содомские браки [...] - это Аргентина [38];

(62) Этот фактор нельзя упускать из внимания при решении современных вопросов и, в частности, проблемы т. н. гей-парада и ЛГБТ-пикетов в Козельске, заявку на проведение которых подал в администрацию города лидер московского содомского сообщества Николай Алексеев... [39].

Przytoczone przykłady wskazują na pełną funkcjonalną synonimię tych form przymiotnikowych. Oznacza to, że kategorie przestrzenne zaczynają ponownie zlewać się z kategoriami moralno-obyczajowymi. Sodoma (miejsce) określa jednocześnie model behawioralny. Stąd już niedaleko do zbudowania analogicznego schematu odnoszącego się do Zachodu (czyli współczesnej Sodomy). Nie jest przypadkiem, że temat homoseksualizmu na Ukrainie wyłania się w badanym dyskursie właśnie w ostatnich latach, kiedy to kraj ten poddał się cywilizacyjnemu wpływowi Zachodu, np.:

(63) Недаром же главный содомит Украины, [...] заявляет, что „вся оппозиция к нам церковная, или околоцерковная" [2]; 
(64) В этом документальном видеофильме отображены события 25 мая, когда в день города Киева международное гомосексуальное лобби сделало попытку провести так называемый парад пидерастов в столице Украины [40].

Elementy gniazda słowotwórczego z rdzeniem содом- są w badanych tekstach wykorzystywane najczęściej dlatego, że w związku z silnym nacechowaniem aksjologicznym pozwalają unikać stosowania innych mocno zaksjologizowanych jednostek należących już do niższych rejestrów stylistycznych. Nic dziwnego, że w środowisku konserwatywno-prawosławnym na pierwszy plan wysuwają się jednostki motywowane biblijnie, a bogactwo ich form jest niezaprzeczalnym potwierdzeniem ich aktualności w badanym dyskursie. Z pragmatycznego punktu widzenia, z perspektywy celów, jakie prawdopodobnie przyświecają nadawcom badanych tekstów, leksemy należące do analizowanej grupy są optymalnym wyborem, ponieważ ich wydźwięk jest bardzo mocny, wyrazisty, są one aksjologicznie jednoznaczne, ale jednocześnie nie spychają dyskursu w kierunku wulgarności. Intensywność wyzyskiwania analizowanych jednostek w badanym dyskursie, bogactwo form i w ogóle stała obecność tematyki homoseksualizmu traktowanego jako zjawisko negatywne wskazuje na istotność tej kwestii dla danego środowiska - ultraprawosławnych rosyjskich nacjonalistów.

\section{Bibliografia}

Bogatova, Galina Aleksandrovna, red. Slovar' russkogo âzyka XI-XVII vv., vyp. 26. Moskva, Nauka, 2004.

Čudinov, Aleksandr Nikolaevič. Slovar' inostrannyh" slov", vošedših" v" sostav" russkago âzyka. Sankt-Peterburg". Izdanie knigoprodavca Vasiliâ Ivanoviča Gubinskogo. Tipografiâ Sergeâ Nikolaeviča Hudekova, 1894.

Dal', Vladimir Ivanovič. Tolkovyj slovar' živago velikoruskago âzyka. Tom četvertyj. Sankt-Peterburg", Izdanie knigoprodavca-tipografa M. O. Vol'fa, 1882.

Długosz-Kurczabowa, Krystyna. Apelatywizacja biblijnych nazw własnych w języku polskim. Wrocław-Warszawa-Kraków, Ossolineum, 1990.

Evans, James Allan. Justynian i imperium bizantyjskie. Przeł. Barbara Godzińska. Warszawa, Bellona, 2008.

Fasmer, Max. Ètimologičeskij slovar' russkogo âzyka. T. 4. Moskva, Progress, 1987.

Herek, Gregory M. „Beyond «homophobia»: Thinking about sexual prejudice and stigma in the twenty-first century”. Sexuality Research and Social Policy, 1 (2), 2004, s. 6-24.

Kon, Igor' Semenovič. Liki i maski odnopoloj lûbvi. Lunnyj svet na zare. Moskva, AST-Olimp, 2003.

Kuznecov, Sergej Aleksandrovič. Bol'šoj tolkovyj slovar' russkogo âzyka. Sankt-Peterburg, Norint, 2000.

Laboratoriâ issledovanij seksual'nosti. Nasilie protiv LGBT v Rossi po dannym media. Sankt-Peterburg, 2017. Web. 14.03.2019. https://lgbtrightsinrussia.files.wordpress.com/2017/09/otchet-media-hate.pdf. 
Orlova, Nadežda Mihajlovna. „Dinamičeskij harakter biblejskoj precedentnosti”. Izvestiâ Saratovskogo universiteta. T. 9. Sociologiâ. Politologiâ, vyp. 1, 2009, s. 46-53.

Ožegov, Sergej Ivanovič. Slovar' russkogo âzyka. Moskva, Izdatel'stvo „Russkij âzyk”, 1988.

Rutkowski, Mariusz. Nazwy wtasne w strukturze metafory i metonimii. Olsztyn, Wydawnictwo UWM, 2007.

Sorokoletov, Fedor Pavlovič, red. Slovar' russkih narodnyh govorov, vyp. 39. Sankt-Peterburg, Nauka, 2005.

Sozaev, Valerij. Kak izbežat' ispol'zovaniâ âzyka vraždy v otnošenii lesbiânok, geev, biseksualov, transgenderov. Rukovodstvo dlâ žurnalistov. Moskva, Moskovskaâ hel'sinkskaâ gruppa, 2013.

Švedova, Nataliâ Ûl'evna. Tolkovyj slovar' russkogo âzyka s vklûčeniem svedenij o proishoždenii slov. Moskva, Azbukovnik, 2011.

Ušakov, Dmitrij Nikolaevič. Tolkovyj slovar' Ušakova onlajn. Web. 11.03.2019. https://ushakovdictionary.ru/.

Zygmont, Aleksej Igorevič. „Problematika nasiliâ v Russkoj pravoslavnoj cerkvi v postsovetskij period". Gosudarstvo, religiâ, cerkov'v Rossii i za rubežom, nr 3, 2014, s. 117-145.

LiveInternet.ru. Web. 30.12.2018. https://www.liveinternet.ru/stat/3rm.info/index.html?perio$\mathrm{d}=$ month.

Moskva - Tretij Rim. Web. 04.01.2019. http://3rim.info/1117-obnovleno-prodolzhenie-kak-my-pederastov-gonyali-iz-pervyx-ust-video-foto.html.

Rambler. Web. 30.12.2018. https://top100.rambler.ru/navi/?theme=1166\%2F1167\&resourceId= 2421338 \&page $=3 \# 2421338$.

\section{Źródła przykładów}

[1] Râbčenko, Lûdmila. Pust' pravoslavnye sami uničtožat svoi cennosti. Web. 11.03.2019. https://3rm.info/publications/45252-pust-pravoslavnye-sami-unichtozhat-svoi-cennosti.html.

[2] Vatikan i, ,cerkov' èvtanazii”. Web. 11.03.2019. https://3rm.info/publications/34911-vatikan-i-cerkov-evtanazii.html.

[3] Četverikova, Ol'ga. Postsobornaâ cerkov'. Web. 11.03.2019. https://3rm.info/publications/ 64848-postsobornaya-cerkov-olga-chetverikova.html.

[4] Bobylev, Evgenij. Telegoniâ - nakazanie za blud... Web. 11.03.2019. https://3rm.info/publications/58636-telegoniya-nakazanie-za-blud-pr.html.

[5] Pavlov, Aleksandr. K čemu vedut „cennosti”, navâzyvaemye nam apostasijnoj Evropoj? Web. 11.03.2019. https://3rm.info/publications/34085-k-chemu-vedut-cennosti-navyazyvaemye-nam -apostasiynoy-evropoy.html.

[6] Terleckij, Aleksandr. Dostoevskij protiv evrosodoma. Segodnâ aktual'no, kak nikogda! Web. 11.03.2019. https://3rm.info/publications/41300-dostoevskiy-protiv-evrosodoma-segodnya-aktualno-kak-nikogda.html.

[7] Evrosodom. Za otkaz ot seksprosveta - tûr'ma! Web. 11.03.2019. https://3rm.info/publications/ 38195-evrosodom-za-otkaz-ot-seksprosveta-tyurma-video.html.

[8] Obozrevšij evrosodom... Evrokomissiâ obvinila patriarha Iliû II v netolerantnosti. Web. 11.03.2019. https://3rm.info/main/73161-oborzevshij-evrosodom-evrokomissija-obvinila-patriarha-iliju-ii-v-netolerantnosti.html.

[9] Adskij Evrosodom... Dlâ teh, kto hočet v Evropu. Detskie ploŝadki v pedofil'skom stile. Web. 11.03.2019. https://3rm.info/main/51899-evrosodom-detskie-ploschadki-v-pedofilskom-stilefoto.html. 
[10] Planeta Sodom... Propaganda izvraŝenij dlâ detej: Disnej snimaet pervyj fil'm o pederaste. Web. 11.03.2019. https://3rm.info/main/72214-planeta-sodom-propaganda-izvrascheniy-dlya-detey-disney-snimaet-pervyy-film-o-pederaste-video.html.

[11] Planeta Sodom..., ,Gomoseksualizm” stal predmetom v školah SŠA. Web. 11.03.2019. https:// 3rm.info/main/70092-planeta-sodom-gomoseksualizm-stal-predmetom-v-shkolah-ssha. html.

[12] Planeta Sodom... Tehnologiâ prodviženiâ izvraŝenij v Rossii. Web. 11.03.2019. https://3rm. info/publications/58539-planeta-sodom-tehnologiya-prodvizheniya-izvrascheniy-v-rossii-video.html.

[13] Planeta Sodom... Sodomity gotovât massirovannoe napadenie na Rossiû. Web. 11.03.2019. https://3rm.info/main/72080-planeta-sodom-sodomity-gotovyat-massirovannoe-napadenie-na-rossiyu.html.

[14] Sodomskie Štaty Ameriki... V N'û-Jorke v svidetel'stvah o roždenii poâvilas' genderno-nejtral'naâ kategoriâ „X”. Web. 11.03.2019. https://3rm.info/main/72996-sodomskie-shtaty-ameriki-v-nju-jorke-v-svidetelstvah-o-rozhdenii-pri-ukazanii-pola-rebenka-pojavilas-genderno-nejtralnaja-kategorija-x.html.

[15] S Š́ - Sodomskie Štaty Ameriki... Senat štata Illinojs progolosoval za prepodavanie istorii LGBT v škole. Web. 11.03.2019. https://3rm.info/main/71240-ssha-sodomskie-shtaty-ameriki-senat-shtata-illinoys-progolosoval-za-prepodavanie-istorii-lgbt-v-shkole.html.

[16] Sodomskie Štaty Ameriki - Sک̌A... Kaliforniâ vvodit zapret na «popytki lečeniâ» sodomii. Web. 11.03.2019. https://3rm.info/main/70978-sodomskie-shtaty-ameriki-ssha-kaliforniya-vvodit-zapret-na-popytki-lecheniya-sodomii.html.

[17] Svâsennoe pisanie o ,evropejskih cennostâh” - polovyh izvraŝeniâh. Web. 11.03.2019. https://3rm.info/publications/35467-svyaschennoe-pisanie-o-evropeyskih-cennostyah-polovyh-izvrascheniyah.html.

[18] Zri v koren'... Sodom v predvkušenii pobedy nad Rossiej. Smotri, č'imi rukami kuetsâ èta pobeda. Web. 11.03.2019. http://3rm.info/9558-zri-v-koren-sodom-v-predvkushenii-pobedynad-rossiej-smotri-chimi-rukami-kuetsya-eta-pobeda.html.

[19] Diversiâ protiv Rossii... Sodom trebuet prav $i$ vlasti, gosudarstvo emu daet. Web. 11.03.2019. https://3rm.info/main/70800-diversiya-protiv-rossii-sodom-trebuet-prav-i-vlasti-gosudarstvo-emu-daet.html.

[20] Râbičenko, Lûdmila Arkad'evna. Global'naâ transformaciâ... S podači korolevskogo doma Anglii mir nakryvaet sodomskâ̂ revolûciâ. Web. 11.03.2019. https://3rm.info/main/ 71871-globalnaya-transformaciya-s-podachi-korolevskogo-doma-anglii-mir-nakryvaet-sodomskaya-revolyuciya.html.

[21] Vostrâkov, Nikolaj. Gor'kie plody vospitaniâ bez Boga. Web. 11.03.2019. https://3rm.info/ publications/43603-gorkie-plody-vospitaniya-bez-boga.html.

[22] Filimonov, Valerij Pavlovič. Vsemirnyj sodom rukopleŝet... Smena pola v Rossii - pod zakonom. Web. 11.03.2019. https://3rm.info/main/70247-vsemirnyy-sodom-rukopleschetsmena-pola-v-rossii-pod-zakonom.html.

[23] Sodomitskaâ merzost' vpolzaet v cerkov'... Drug mitropolita Ilariona rasskazal o „,glubokoj lûbvi" meždu sodomitami. Web. 11.03.2019. https://3rm.info/main/71683-sodomitskaya-merzost-vpolzaet-v-cerkov-drug-mitropolita-ilariona-rasskazal-o-glubokoy-lyubvi-mezhdu-sodomitami.html.

[24] Zisis, Feodor. Vsled za èkumenizmom prišel gomoseksualizm. Web. 11.03.2019. https://3rm. info/publications/63526-vsled-za-ekumenizmom-prishel-gomoseksualizm-protopresviter-feodor-zisis.html. 
[25] Liberal'naâ tusovka protalkivaet Sodom i Gomorru v pravoslavnuû cerkov'. Web. 11.03.2019. https://3rm.info/publications/63453-liberalnaya-tusovka-protalkivaet-sodom-i-gomorru-v-pravoslavnuyu-cerkov.html.

[26] O licedeâh: Vozvedennoe v kul'tiskusstvo vrat'. Gniûsie otbrosy vseh vremen i narodov -,,gospoda" licedei! Web. 11.03.2019. https://3rm.info/publications/64234-o-licedeyah-vozvedennoe-v-kult-iskusstvo-vrat.html.

[27] Cena uspeha v šoubiznese... Dmitrij Malikov raskryl svâzannyj s geâmi i evreâmi sekret uspeha. Web. 11.03.2019. http://3rim.info/12407-cena-uspeha-v-shou-biznese-dmitriy-malikov-raskryl-svyazannyy-s-geyami-i-evreyami-sekret-uspeha.html.

[28] Mel'nikov, Dmitrij. Zapad v vojne protiv Hrista... Nasil'stvennaâ antikanoničeskaâ avtokefalizaciâ kak oružie vragov Pravoslaviâ i slavânstva. Web. 11.03.2019. https://3rm.info/main/ 72231-zapad-v-voyne-protiv-hrista-nasilstvennaya-antikanonicheskaya-avokefalizaciya-kak-oruzhie-vragov-pravoslaviya-i-slavyanstva.html.

[29] Vot tak razrušaût našu cerkov'!... Ohlobystin: Cerkov' emu nravitsâ, no poka on budet rastlevat' narod. S razrešeniâ patriarha. Web. 11.03.2019. https://3rm.info/main/70556-vot-tak-razrushayut-nashu-cerkov-ohlobystin-cerkov-mne-nravitsya-no-poka-ya-budu-rastlevat-narod.html.

[30] Četverikova, Ol'ga. Vas obâzatel'no obmanut. Ne vedites' na mežcerkovnyj dialog s katolika$m i$. Web. 11.03.2019. https://3rm.info/publications/58753-ne-vedites-na-mezhcerkovnyy-dialog-s-katolikami-vas-obyazatelno-obmanut-on-chetverikova.html.

[31] Plameneet molitvennyj meč. Rus' svâtû̂ angely hranât! Web. 11.03.2019. https://3rm.info/ publications/60560-plameneet-molitvennyy-mech-rus-svyatuyu-angely-hranyat.html.

[32] Èto prosto užas! Detej v lagerâ perevospitaniâ. V Niderlandah gomofobov lišaût roditel'skih prav i otbiraût detej. Web. 11.03.2019. https://3rm.info/main/72975-jeto-prosto-uzhas-detej-v-lagerja-perevospitanija-v-niderlandah-gomofobov-lishajut-roditelskih-prav-i-otbirajut-detej.html.

[33] Planeta Sodom... Konec Evropy: na gej-parad v Švecii vlasti obâzali vyjti voennyh, policejskih i sotrudnikov MID. Web. 11.03.2019. https://3rm.info/main/72128-planeta-sodom-konec-evropy-na-gey-parad-v-shvecii-vlasti-obyazali-vyyti-voennyh-policeyskih-i-sotrudnikov-mid.html.

[34] Bor, Hakin. Okolofutbol'noe skotstvo... Blud, vojna na uničtoženie i novyj trend v propagande. Web. 11.03.2019. https://3rm.info/main/71902-okolofubolnoe-skotstvo-blud-voyna-na-unichtozhenie-i-novyy-trend-v-propagande.html.

[35] Evrosodom... Glubiny sataninskie. V Evrope opravdyvaût pedofiliû. Web. 11.03.2019. https:// 3rm.info/main/71868-evrosodom-glubiny-sataninskie-v-evrope-opravdyvayut-pedofiliyu. $\mathrm{html}$.

[36] Dobyčin, Aleksej. Vosstan' «četverodnevnaâ Rossiâ»! Čast'III-Sobornyj greh. Web. 11.03.2019. https://3rm.info/publications/1776-vosstan-chetverodnevnaya-rossiya-chast-iii.html.

[37] Arhimandrit Rafail (Karelin). Neuželi Sodom - naš buduŝij dom? Gomoseksualistami ne roždaûtsâ - imi stanovâtsâ. Web. 11.03.2019. https://3rm.info/publications/58872-neuzheli-sodom-nash-buduschiy-dom-gomoseksualistami-ne-rozhdayutsya-imi-stanovyatsya-arhimandrit-rafail-karelin.html.

[38] Četverikova, Ol'ga. "Iezuitskaâ petlâ dlâ Rossii”. Čast' pervaâ. Web. 11.03.2019. https://3rm. info/publications/62887-iezuitskaya-petlya-dlya-rossii-chast-pervaya-on-chetverikova.html.

[39] Strogova, Elena. Obozrevšie sodomity... Podana zaâvka na razrešenie gej-parada râdom s Optinoj Pustyn'û. Web. 11.03.2019. https://3rm.info/main/73039-nashestvie-sodomitov-podana-zajavka-na-razreshenie-gej-parada-rjadom-s-optinoj-pustynju.html.

[40] Gomoseksual'nyj terrorizm zahlestnul planetu. Web. 11.03.2019. https://3rm.info/publications/37796-gomoseksualnyy-terrorizm-zahlestnul-planetuvideo.html. 
